\title{
Study on Urban Trees in Ekiti State University, Ado Ekiti, Nigeria: 1. Structure and Composition
}

\author{
Iyanuoluwa Kikelomo Ajayi ${ }^{1}$, Joshua Kayode ${ }^{1}$, Benson Oluwafemi Ademiluyi ${ }^{1}$ \\ ${ }^{I}$ Department of Plant Science and Biotechnology,Ekiti State University, Ado-Ekiti, Nigeria \\ joshua.kayode@eksu.edu.ng
}

\begin{abstract}
An inventory of tree biodiversity was carried in Ekiti State University, Ado-Ekiti, Nigeria, which is an institution where ecological and economic roles of trees are disseminated. The study involved the use of a stratified sampling technique to carry out a survey of trees species in the University. The campus was divided into four strata - Road side (A), Car parks $(B)$, Office area $(C)$, Student halls/ religion area (D) - and each stratum was further subdivided into sub-strata. All the trees within each sub-stratum were identified to species level with their scientific, local and family names and they were counted and recorded. The relative frequency, relative density and relative abundance of the identified species were determined. Similarities indices and indices of diversity were determined on the tree species sampled among the strata. The results obtained revealed that a total of 27 tree species, belonging to 17 families were sampled in the campus. The family Caesalpiniaceae has the highest number of species. Some of the identified tree species were found in multiple and dual strata while some occurred in only one stratum. A total of 838 tree individuals were obtained. The most frequently occurring species were T. grandis, G. arborea and P. longifolia with 298, 181 and 149 individuals respectively. The indices of similarities among the strata were low. However Strata $A$ and $B$ as well as $A$ and $C$ appeared to be similar in tree composition. Strategies that would improve and maintain tree composition in the University campus were proposed.
\end{abstract} Keywords: Urban trees; university; structure; composition

\section{Introduction}

Recent initiatives are now focusing on trees and their roles in the maintenance of the quality of the environment. A growing number of literatures, such as Nowak (2006), Yanga, (2005), Escobedo and Nowak (2009), Escobedo (2011), asserted that trees are important component of urban forest. Urban forests include trees and forests located in the cities, ornamental, street and parkland trees, protected forest and green areas. These trees, according to Beckett (2000) and Singh (2002), affect local and regional air quality by removing atmospheric pollutants and chemicals from the vegetation, altering urban micro-climates by lowering temperatures through shading, evapotranspiration, changing wind patterns, modifying boundary layer height and reducing building energy use and consequent emissions from power plants.

Similarly, Kayode (2008), Patel and Patel (2013), Ayo (2013), Ihimikaiye and Tanee (2014) observed that trees constitutes an integral part of human existence as they provide human with raw materials, foods, shelter, clothing, medicine, oral care, fuel wood, wood craft, as well as fodder and forage for livestock. Despite all these important products and services rendered by trees, Ayeni and Kayode (2008) as well as Kayode et. al. (2016) asserted that urban forest is poor in the residential areas of Ekiti State, Nigeria. A myriad of reasons were attributed to the poor tree cultivation habit in Ekiti State, Nigeria in previous studies conducted by Kayode and Kadeba (2001), Ayeni and Kayode (2004, 2008), as well as Kayode (2010). Thus a deliberate tree cultivation habit especially in schools, churches, colleges and universities was one of the strategies prescribed to address the apparent dearth of trees in the State. 
Consequent on the above, the inventory and assessment of tree biodiversity in different habitats was considered as necessary for the evolvement of long term strategies that will conserve the endangered trees species in the country where tree demography of 560 tree species was enumerated at her independence six decades ago (Ihenyen, 2009). One of such habitat is the Ekiti State University, Ado-Ekiti, Nigeria, a citadel of knowledge where ecological and economic roles of trees are embedded in the knowledge disseminated by the institution. A high expectation that this institution will be rich in tree species of diverse importance abound yet records revealed that there has been no enumeration of trees species in the institution in her 37 years of existence.

The study being reported here is therefore expected to provide basic data on the composition of trees species in the institution, prescribe the appropriate local management strategy for conservation of trees in the University.

\section{Materials and Methods}

\subsection{The Study Area}

The study was conducted in Ekiti State University campus, Ado Ekiti, Ekiti State of Nigeria (Obembe and Kayode 2019). It is geographically located on Latitude $7^{0} 12^{\prime} \mathrm{N}$ and Longitude $5^{0} 25^{\prime}$ E. The area has two climatic seasons-a rainy season and a dry season, the annual rainfall is about $1150 \mathrm{~mm}$. Ekiti State University was established in the year 1982 and it is owned by Ekiti State Government of Nigeria.

\subsection{Methods}

This study involved the survey of trees species in Ekiti State University, Ado-Ekiti, Nigeria's campus. A stratified sampling technique was used in the study. The University Campus was divided into four strata and each stratum was further sub-divided into sub-strata (Table 1). All the trees within each of the sub-stratum were identified to species level with their scientific, local and family names and counted. Voucher specimen of the identified trees were obtained and taken to the herbarium of the Department of Plant Science and Biotechnology for proper authentication and the specimen deposited. Voucher numbers were assigned to the specimen.

Table 1. Stratification of the Ekiti State University, Ado-Ekiti, Nigeria's campus for tree inventory

\begin{tabular}{|c|c|c|}
\hline $\mathrm{S} / \mathrm{N}$ & STRATA & SUB- STRATA \\
\hline \multirow[t]{5}{*}{$\mathrm{A}$} & \multirow[t]{5}{*}{ Road side } & Main gate - Omolayo building \\
\hline & & Roundabout - Faculty of Engineering A2 \\
\hline & & United Bank for Africa - Library A3 \\
\hline & & Former part-time programme Block \\
\hline & & Library - Car park \\
\hline \multirow[t]{5}{*}{ B } & \multirow[t]{5}{*}{ Car park } & Faculty of Agriculture \\
\hline & & Faculty of Science \\
\hline & & Faculty of Management Science \\
\hline & & Faculty of Education \\
\hline & & College of Medicine \\
\hline \multirow[t]{4}{*}{$\mathrm{C}$} & \multirow[t]{4}{*}{ Office area } & Omolayo building \\
\hline & & Library \\
\hline & & Health centre \\
\hline & & New senate building \\
\hline
\end{tabular}




\begin{tabular}{|l|l|lc|}
\hline \multirow{3}{*}{ D } & & \multicolumn{2}{|c|}{ emails:birex.journal@gmail.com } \\
& \multirow{3}{*}{ Student halls/ religion area } & Sandwich building & C5 \\
\cline { 3 - 4 } & & New hostel & D1 \\
\cline { 3 - 4 } & & Government hostel & D2 \\
\cline { 3 - 4 } & & Ajasin hostel & D3 \\
\cline { 3 - 4 } & & Catholic church & D4 \\
\cline { 3 - 4 } & Mosque & D5 \\
\hline
\end{tabular}

The following data were determined in each sub- stratum:

(i) Relative frequency $(\mathrm{RF})=$ Frequency of each species/ Total frequency of all species $\mathrm{x} 100$

(ii) Relative density (RD) = Density of each species/ Total density from all species x 100

(iii) Relative abundance of species (pi) = Relative density of species $/ 100$

Similarities indices were determined on the tree species sampled among the strata as follows:

(i) Index of similarity (IS), according to Kayode (1990) :

IS $=2 \mathrm{Cx} 100 /(\mathrm{A}+\mathrm{B})$

(ii) Jaccard index $\left(\mathrm{S}_{\mathrm{J}}\right)$, according to Gurevitch et. al. (2000):

$\mathrm{S}_{\mathrm{J}}=\mathrm{C} /(\mathrm{A}+\mathrm{B}+\mathrm{C})$

(iii) Ochioi index $\left(\mathrm{S}_{\mathrm{O}}\right)$, according to Gurevitch et. al. (2000):

$\mathrm{S}_{\mathrm{O}}=\mathrm{C} / \sqrt{ }(\mathrm{A}+\mathrm{C})+\sqrt{ }(\mathrm{B}+\mathrm{C})$

(iv) Sorensen -dice index ( $\mathrm{S} \mathrm{SD})$, according to Gurevitch et. al. (2002):

$\mathrm{S}_{\mathrm{SD}}=2 \mathrm{C} /(\mathrm{A}+\mathrm{B}+2 \mathrm{C})$

(v) Asymmetrical similarity ( $\left.\mathrm{S}_{\mathrm{AS}}\right)$, according to Gurevitch et. al. (2002) :

$\mathrm{S}_{\mathrm{AS}}=\mathrm{B} /(\mathrm{B}+2 \mathrm{C})$

Where $\mathrm{A}$ is the number of species in first stratum only;

$\mathrm{B}$ is the number of species in second stratum only;

$\mathrm{C}$ is the number of species common to both strata.

Similarly, the following indices of diversity will be determined as follows:

(i) Simpson index (C), according to Bongers et. al.(1988).

$\mathrm{C}=\sum \mathrm{pi}^{2}$

Where;

$$
\begin{aligned}
& \mathrm{C}=\text { Simpson's index } \\
& \mathrm{Pi}=\mathrm{ni} / \mathrm{N} \\
& \mathrm{ni}=\text { number of individual of species I and } \\
& \mathrm{N}=\text { total number of all individual }
\end{aligned}
$$

(ii) Shannon - Wiener diversity index $\left(\mathrm{H}^{\prime}\right)$, according to Shannon and Wiener $\mathrm{H}^{\prime}=-\sum \mathrm{pi} \ln \mathrm{pi}$

Where;

$$
\begin{aligned}
& \mathrm{P} \mathrm{i}=\text { ni/N, } \\
& \mathrm{ni}=\text { number of individual of one species } \\
& \mathrm{N}=\text { total number of all individuals } \\
& \text { Log = logarithm } \\
& \mathrm{H}^{\prime}=\text { Shannon-Wiener diversity index }
\end{aligned}
$$

(iii) Species evenness will also be determined using Shannon's Equitability Index (E), according to Shannon-Wiener

$$
\begin{aligned}
& \mathrm{E}=\mathrm{H}^{\prime} / \mathrm{H}_{M} \\
& \text { Where; } \\
& \quad \mathrm{H}_{\mathbf{M}}=\ln \mathrm{S} \\
& \mathrm{S}=\text { number of species } \\
& \quad \mathrm{H}^{\prime}=\text { Shannon-Wiener index }
\end{aligned}
$$




\section{Results}

emails: birex.journal@gmail.com

The results obtained revealed that a total of 27 tree species, belonging to 17 families were sampled in the campus (Table 2). The family Caesalpiniaceae has the highest number of species (6 species). The family Combretaceae has three species, families Anacardiaceae, Moraceae and Verbernaceae, each has two species while other families possess one species each. Table 2 also shows that some of the identified tree species were found in multiple and dual strata while some occurred in only one stratum. For example, while Carica papaya and Gmelina arborea were found in all the strata used, Anacardium occidentale, Bauhinia monandra, Delonix regia, Hura crepitan, Polyathia longifolia, Senna grandis, Tectonia grandis and Terminalia mantaly were each found in three of the strata sampled. Mangifera indica, Pinus caribaea, Roystonea regia and Terminalia catappa were each found in two of the strata while Auracaria cunningamii, Bauhinia purpurea, Citrus sinensis, Cochlospermum gossypium, Elaeis guineensis, Eucalyptus deglupta, Ficus thonningii, Ficus sur, Holarrhena floribunda, Parkia biglobosa, Peltophorum pterocarpium and Terminalia schimperiana, each occurred in a stratum.

Table 2. Checklist of tree species identified in EKSU Campus, Ado-Ekiti, Nigeria

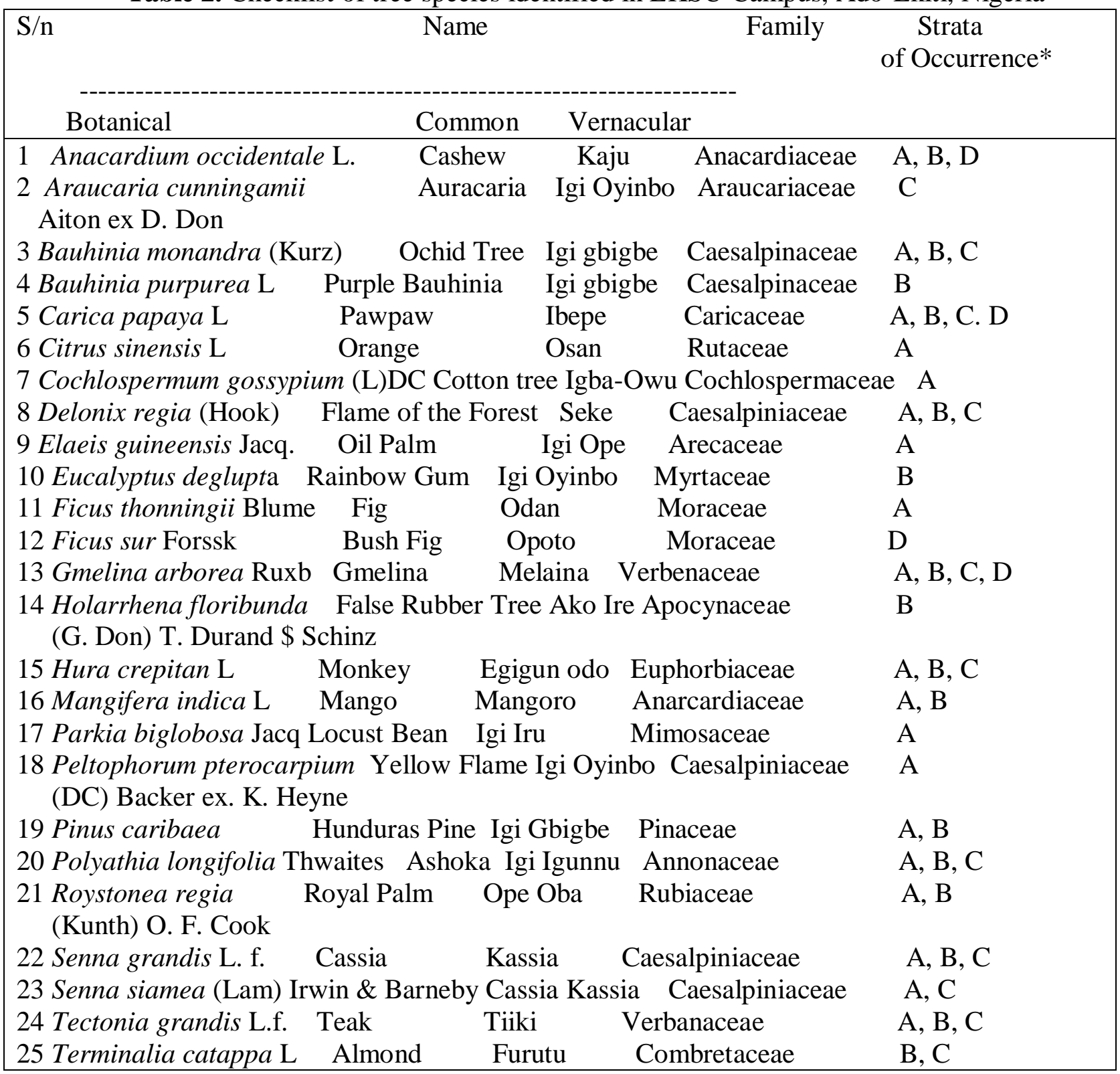



emails: birex.journal@gmail.com

26 Terminalia mantaly Step Tree Afara Oyinbo Combretaceae A, B, C (H. Pierrer)

27 Terminalia schimperiana

Udi

Combretaceae

A

The demographic classification of tree species identified in EKSU Campus, Ado-Ekiti, Nigeria was shown in Table 3. A total of 552, 235, 39 and 12 belonging to 21, 17, 12 and 4 families were sampled in Stratum, A, B, C and D respectively. G. arborea, T. grandis $P$. longifolia as well as T. mantaly and C. papaya were the most abundant trees in Stratum, A, B, $\mathrm{C}$ and D respectively. These constituted 32\%, 64\%, 15\% (each) and 50\% of the trees sampled in Stratum, A, B, C and D respectively. The diversity indices revealed that diversity of trees abounds in the different strata of the study area. Equitability Index values of 0.6051, 2.1085, 0.9101 and 0.7905 were recorded for stratum A, B, C and D respectively.

Table 4 shows the population of each of the 27 identified trees all the strata used in the study area. A total of 838 tree individuals were obtained. The most frequently occurring species (Table 5) revealed that T. grandis, G. arborea and P. longifolia with 298, 181 and 149 individuals respectively, dominated the trees found on the campus.

Table 3. Demographic classification of tree species identified in EKSU Campus, Ado-Ekiti, Nigeria

\begin{tabular}{|c|c|c|c|c|}
\hline \multirow[t]{2}{*}{ Description } & \multicolumn{3}{|c|}{ Strata } & \multirow[b]{2}{*}{$\mathrm{D}$} \\
\hline & A & B & $\mathrm{C}$ & \\
\hline No. of trees observed & 552 & 235 & 39 & 12 \\
\hline No. of tree species & 21 & 17 & 12 & 4 \\
\hline Most abundant tree species & G.arborea & T. grandis & $\begin{array}{l}\text { P. longifolia } \\
\& \\
\text { T. mantaly }\end{array}$ & C. papaya \\
\hline$\%$ of the most abundant speci & $32 \%$ & $64 \%$ & $15 \%$ (each) & $50 \%$ \\
\hline Relative abundance of the spe & ecies 0.0032 & 0.0064 & 0.0015 (each) & 0.0050 \\
\hline Simpson Index / Stratum & 0.2249 & 0.4231 & 0.202 & 0.3747 \\
\hline Shannon-Weiner Diversity / & Stratum 1.846 & 1.5226 & 2.274 & 1.088 \\
\hline Equitability Index / Stratum & 0.6051 & 2.1085 & 0.9101 & 0.7905 \\
\hline
\end{tabular}

Table 4. Population of Identified Trees in different strata of EKSU Campus, Ado-Ekiti, Nigeria

\begin{tabular}{|c|c|c|c|c|c|c|}
\hline \multirow[t]{2}{*}{$\mathrm{S} / \mathrm{n}$} & \multirow[t]{2}{*}{ Tree Species } & \multicolumn{4}{|c|}{ Strata } & \multirow[t]{2}{*}{ Tota } \\
\hline & & $\mathrm{A}$ & B & $\mathrm{C}$ & $\mathrm{D}$ & \\
\hline 1 & A. occidentale & 2 & 2 & - & 4 & 8 \\
\hline 2 & A. cunningamii & - & - & 2 & - & 2 \\
\hline 3 & B. monandra & 8 & 15 & 5 & - & 28 \\
\hline 4 & B. purpurea & - & 4 & - & - & 4 \\
\hline 5 & C. papaya & 2 & 7 & 1 & 6 & 16 \\
\hline 6 & C. sinensis & 1 & - & - & - & 1 \\
\hline 7 & C. gossypium & 4 & - & - & - & 4 \\
\hline 8 & D. regia & 18 & 2 & 2 & - & 22 \\
\hline 9 & E. guineensis & 1 & - & - & - & 1 \\
\hline 10 & E. deglupta & - & 1 & - & - & 1 \\
\hline 11 & F. thonningii & 1 & - & - & - & 1 \\
\hline 12 & G. arborea & 174 & 3 & 3 & 1 & 181 \\
\hline 13 & H. floribunda & - & 1 & - & - & 1 \\
\hline 14 & H. crepitan & 8 & 11 & 4 & - & 23 \\
\hline 15 & M. indica & 1 & 2 & - & - & 3 \\
\hline
\end{tabular}




\begin{tabular}{|l|l|l|r|r|r|c|}
\hline 16 & P. biglobosa & 2 & - & - & - & 2 \\
\hline 17 & P. ptericarpium & 3 & - & - & - & 3 \\
\hline 18 & P. caribaea & 6 & 3 & - & - & 9 \\
\hline 19 & P. longifolia & 125 & 18 & 6 & - & 149 \\
\hline 20 & R. regia & 4 & 10 & - & - & 14 \\
\hline 21 & S. grandis & 1 & 2 & 5 & - & 8 \\
\hline 22 & S. siamea & 16 & - & 2 & - & 18 \\
\hline 23 & T. grandis & 147 & 150 & 1 & - & 298 \\
\hline 24 & T. catapa & - & 2 & 2 & - & 4 \\
\hline 25 & T. mantaly & 9 & 2 & 6 & - & 17 \\
\hline 26 & T. schimperiana & 1 & - & - & - & 1 \\
\hline 27 & F. sur & - & - & - & 1 & 1 \\
\hline & & 552 & 235 & 39 & 12 & 838 \\
Total & & & & & & \\
\hline
\end{tabular}

Table 5. Rank order of the 10 most frequently occurring tree species in EKSU Campus, AdoEkiti, Nigeria

\begin{tabular}{|c|c|c|}
\hline Rank & Tree species & $\begin{array}{l}\text { No. of } \\
\text { Individuals }\end{array}$ \\
\hline 1 & T. grandis & 298 \\
\hline 2 & G. arborea & 181 \\
\hline 3 & P. longifolia & 149 \\
\hline 4 & B. monandra & 28 \\
\hline 5 & S. grandis & 26 \\
\hline 6 & H. crepitan & 23 \\
\hline 7 & D. regia & 22 \\
\hline 8 & S. siamea & 18 \\
\hline 9 & C. papaya & 18 \\
\hline 10 & T. mantaly & 17 \\
\hline
\end{tabular}

The indices of similarities (Table 6) revealed that strata B and C with 69, 0.26, 0.99 and $0.38, I S, S_{J}, S_{O}$ and $S_{S D}$ values respectively appeared to be similar in tree composition.

Similarly, Strata A and B with IS, $S_{J}$, So and S SD values of 68.4, 0.25, 1.12 and 0.41, and Strata $A$ and $C$ with $I S, S_{J}, S_{O}$ and $S_{S D}$ values of $23.1,0.10,0.38$ and 0.19 , appeared fairly similarly in tree composition

Table 6. Indices of similarities in the occurrence of tree in EKSU Campus, Ado-Ekiti, Nigeria

\begin{tabular}{|llllcc|}
\hline Strata & IS & $\mathrm{S}_{\mathrm{J}}$ & $\mathrm{S}_{\mathrm{O}}$ & $\mathrm{S}_{\mathrm{SD}}$ & $\mathrm{S}_{\mathrm{AS}}$ \\
\hline A-B & 68.4 & 0.25 & 1.12 & 0.41 & 0.40 \\
A-C & 60.6 & 0.23 & 0.96 & 0.35 & 0.46 \\
A-D & 23.1 & 0.10 & 0.38 & 0.19 & 0.74 \\
B-C & 69.0 & 0.26 & 0.99 & 0.38 & 0.46 \\
B-D & 27.3 & 0.12 & 0.40 & 0.22 & 0.74 \\
C-D & 21.1 & 0.11 & 0.30 & 0.20 & 0.81 \\
\hline
\end{tabular}

\section{Discussion}

The results from this study revealed that diverse tree species were found in this study area. A number of studies, such as Matsuoka (2010), Wu et al. (2014) and Sivarajah et al. (2018) asserted that the proportion of tree cover is a significant positive predictor of student performance. The effects of tree cover and species composition were most pronounced in 
schools that have high number of trees thus suggesting the importance of urban forestry investments in these schools. Shah, et al. (2014) observed that biodiversity boosts ecosystem productivity where each species, no matter how small, all have an important role to play. Greater species diversity ensures natural sustainability for all life forms. Biodiversity ensures the health of the ecosystems and enables it to better withstand and recover from a variety of disasters. It also possessed a number of social benefits, such as research, education and monitoring that constituted the major assignment of the universities through the world.

Previous studies also enumerated the advantages offered by urban forest, especially on educational environment. Urban forests moderate air temperature (Cummins and Jackson 2001), mitigate ambient air pollution (Nowak et al. 2006), produce human health benefits (Handy et al. 2002, Hansmann et al. 2007, Hartig et al. 2003, Pretty et al 2005 and Takano et. al. 2002). lower human mortality rates (Villeneuve et al. 2012), and generally improve the quality of life of urban inhabitants (Maas et al. 2008, Mitchell and Popham 2008). Similarly, human exposure to green space as been found to result in positive feelings, relaxation, stress relief, and restoration of attention-demanding cognitive performance (Taylor et al. 2001 Park et al. 2011. Pretty et al (2005), Takano et al. (2002) and Villeneuve et al. (2012) have also linked mental health benefits, following exposure to forested areas, with specific physiological responses, including reduced diastolic blood pressure and reduced heart rate.

The results from this study also revealed that the occurrence of the identified tree species were not restricted to a particular stratum. The species were generalists that were not exclusive to a particular stratum. This observation tends to support species occurrence in tropical forest as earlier observed in the study of Mancino et al. (2015). However, more trees were planted by road sides and car-parks. While trees were planted in the forlorn stretches of roadside, no tree planting was done in the highway medians. EarthTalk (2016) enumerated the advantages of planting trees by roadside to include enhancement of livability of urban streets, control of noise pollution. Trees reduce the chance of flood and soil erosion; provide reliefs to humans, birds and animals from sun and rain. Wolf (2006) asserted that roadside soils and vegetation capture reasonable proportion of transportation carbon emissions thus constituting valuable "banks" for meeting ambitious carbon sequestration goals. Also, Parsons et al. (1998) asserted that drivers seeing natural roadside views show lower levels of stress and frustration compared to those viewing all-built settings.

Tree density around offices and students' halls of residence and religious areas were low. Information received from a key-informant during the study revealed administrators of the study area showed lack a daisical attitude towards tree planting. This observation tends to buttress the previous observations of Oladehinde (2016) and Salbitano et al. (2016) that administrators often fail to sufficiently take urban forests as serious issues. Larinde and Oladele (2014), in a study conducted in another University campus in Nigeria, asserted that species composition were scanty in all the student hostels as a result of lack of proper planning, students lacks time to nurse plants, they are unstable, mobile and have no sense of tree ownership while in school.

The study revealed that trees planted in this study were mostly exotic species. Information from key informant revealed that though no reason was attributed to this but the exotic species were observed to establish easily, fast in growth, possess high propagule pressure, and low or intermediate shade tolerance ability thus support the previous assertion of (Dodet and Collet 2012). Oba et. al. (2001) also revealed that the exotics tree species possess the potentials to generate revenue. The trees in students' halls of residence and religious areas were dominated by fruit species. Fruit trees provide important nutrients, vitamins and part of family income (Adeboye and Adedayo, 2008). They also have the he capacity to provide the much desired tree cover and other benefits in urban and peri-urban centres. Also natural disasters including wind storms and surface water erosion can be effectively controlled by heavily branched and deep rooted fruit trees (Larinde and Ogunniyan 2011). 
Budapest International Research in Exact Sciences (BirEx) Journal

Volume 2, No 2, April 2020, Page: 147-156

e-ISSN: 2655-7827 (Online), p-ISSN: 2655-7835(Print)

www.bircu-journal.com/index.php/birex

emails: birex.journal@gmail.com

\section{Conclusion}

The tree sampled in the study area is extremely low compared to the massive area presently being occupied by the University. The study therefore is inclined to describe tree composition in the study area as poor, unplanned and non-scientific. Field observation revealed that they were not properly managed. The attitude of the University Management to tree planting and maintenance should change. More trees should be planted on campus especially at strata $\mathrm{C}$ and $\mathrm{D}$, that is, near offices, students' halls of residence and religious areas, especially now that the University is transiting from the non-residential institution to a residential institution, trees should be planted adequately at the staff quarters. Larinde and Ogunniyan (2011) enumerated the potential of this initiative in urban forestry. Previous suggestion by Soladoye and Oromakinde (2013) that public enlightenment should be carried out on urban forestry is equally relevant here. The use of indigenous trees in urban forestry should be encouraged as some of them are now endangered. Indigenous trees on campus should be preserved. Botanical Garden should be established and adequately stocked with admixture of indigenous and exotic tree species. Diverse edible fruit trees should be planted in the different strata used in this study. Trees on campus must be properly labeled with the summaries of their values. This will confer respects on the trees from members of the University community for the trees.

\section{References}

Adeboye, O. A. and Adedayo, A. (2008). "Nigeria under Exploited Indigenous Fruits Vegetables in Era of Climate Change. A Review of Scientific Literature". Pp: 1-4

Ayeni, J.M. and Kayode, J. (2008)." Survey of Homestead Trees in Ado - Ekiti Region of South Western Nigeria". Bulletin of Pure and Applied Sciences 27B (1 \& 2): 45-55. Ayo F. (2013). "Economic Botany". Keynotes Publishers Limited, Nigeria. 131p.

Bolaji-Olutunji K. A., Adebagbo, C. A., and Tolawo, O. A. (2008). "Enviromental degradation and sustainable food security in Nigeria". Journal of Agriculture, Forestry and Social Sciences, 6(2).

Beckett, K.P., Freer-Smith, P.H., and Taylor, G. (2000). "The Capture of Particulate Pollution by Trees at five Contrasting Urban Sites". Arboriculture Journal. (24):209-230.

Bongers, F., Popma, J., Meave del Castilo, J. and Carabias, J. (1988). "Structure and Floristic Composition of the Lowland Rain Forest of Los Tuxtlas". Vegetation 74, 55-80.

Cummins, S. K, and Jackson, R. J. (2001). "The built environment and children's health" Pediatric Clinics of North America 48(5): 1241-1252.

Dodet, M. and Collet, C. (2012). "When should exotic forest plantation tree species be considered as an invasive threat and how should we treat them?" Biological Invasions 14(9):1765-1778.

EarthTalk (2016). "Why Can't We Plant Trees in Highway Medians?"

https://www.scientificamerican.com/article/why-can-t-we-plant-trees-in-highwaymedians/

Escobedo, F.J., Kroeger, T., Wagner, J.E. (2011). "Urban forests and pollution mitigation: Analyzing ecosystem services and disservices". Environmental Pollution (159):20782087.

Escobedoa, F.J. and Nowak, D.J. (2009). "Spatial Heterogeneity and Air Pollution Removal by an Urban Forest". Landscape and Urban Planning (90):102-110.

Gurevitch, J., Scheiner, S. M. and Fox, G. A. (2002). “The ecology of Plants” Sinauer Associates Inc., Sunderland, MA.

Handy, S., Boarnet, M., Ewing, R. and Killingsworth, R. (2002). "How the built environment affects physical activity”. American Journal of Preventive Medicine23(2):64-73.

DOI: https://doi.org/10.33258/birex.v2i2.872 
Budapest International Research in Exact Sciences (BirEx) Journal Volume 2, No 2, April 2020, Page: 147-156 e-ISSN: 2655-7827 (Online), p-ISSN: 2655-7835 (Print) www.bircu-journal.com/index.php/birex emails: birex.journal@gmail.com

Hansmann, R., Hug, S. M. and Seeland, K. (2007). "Restoration and stress relief through physical activities in forests and parks." Urban Forestry \& Urban Greening 6(4): 213225.

Hartig, T., Evans, G. W., Jamner, L. D., Davis, D.S. and Gärling, T. (2003). "Tracking restoration in natural and urban field settings." Journal of Environmental Psychology. 2003; 23:109-123.

Iheyen, J., Okoegwale, E.E., and Mensah, J.K. (2009). "Composition of Tree Species in Ehor Forest Reserve, Edo State, Nigeria." Nature and Science 7(8): 8 - 18.

Ihimikaiye, S.O. and Tanee, F. B. G. (2014). "Impacts of the Interaction of two links." Landscape and Urban Planning 97(4): 273-282.

Nowak, D.J., Crane, D.E, Stevens, J.C. (2006a). "Air Pollution Removal by Urban Trees and Shrubs in the United States." Urban Forestry and Urban Greening 4:115-123.

Oba, G., Nordal, I., Stenseth, N. C., Stave, J. Bjorå, C. S., Muthondeki, J.K. Bii, W. K. A. (2001). "Growth performance of exotic and indigenous tree species in saline soils in Turkana, Kenya." Journal of Arid Environments 47(4), 499-511.

Obembe, M. O. and Kayode, J. (2019). "Evaluation of the Insecticidal Properties of Cassia alata L. against Cowpea Weevil, Callobruchus maculatus Fab.(Coleoptera: Bruchidae)." Budapest International Journal in Exact Sciences 1 (4), 84-92. DOI: https://doi.org/10.33258/birex.v1i4.481

Oladehinde, R, G, (2016). "Lagos, tree planting and the environment." The Guardian, 30 July 2016.

Parsons, R.,. Tassinary, L. G., Ulrich, R.S., Hebl, M.R. and Grossman-Alexander, M. (1998).” The View From the Road: Implications for Stress Recovery and Immunization." Journal of Environmental Psychology 18, 2:113-140.

Park, B. J., Furuya, K., Kasetani, T, Takayama N., Kagawa, T. and Miyazaki, Y. (2011).

"Relationship between psychological responses and physical environments in forest settings." Landscape and Urban Planning 102(1): 24-32.

Patel, H.R, and Patel, R.S. (2013). "Ethnobotanical of Plant used by the Tribes of R.D.F. Poshina Forest range of Sabaekantha District, North Gujarat, India." International Journal of Scientific and Research Publications 3(2):2250-3153.

Pretty, J., Peacock, J., Sellens, M. and Griffin, M. (2005). "The mental and physical health outcomes of green exercise." International Journal of Environmental Health Research 15(5): 319-337. doi: 10.1080/09603120500155963

Salbitano, F., Borelli, S., Conigliaro, M. and Chen, Y. (2016). "Guidelines on urban and periurban forestry" FAO Forestry Paper No. 178. Food and Agriculture Organization of the United Nations, Rome, 172pp.

Shah, A. (2014). "Why Is Biodiversity Important? Who Cares?" http://www.globalissues.org/article/170/why-is-biodiversity-important-who-cares

Singh, J.S. (2002). "The Biodiversity Crisis: A Multifaceted Review." Current Science, 82:638-647.

Sivarajah, S., Smith, S. M. and Thomas, S. C. (2018). "Tree cover and species composition effects on academic performance of primary school students. PloS ONE 13(2): e0193254. https://doi.org/10.1371/journal.pone.0193254

Soladoye, O. and Oromakinde, O. O. (2013). "Assessment of Tree Planting Efforts in Lagos Island Local Government Area of Lagos State, Nigeria." Environment and Natural Resources Research 3 (4): 12-18.

Takano, T., Nakamura, K. and Watanabe, M. (2002). "Urban residential environments and senior citizens' longevity in megacity areas: the importance of walkable green spaces." Journal of Epidemiology and Community Health . 56: 913-918.

Taylor, A. F., Kuo, F. E. and Sullivan, W. C. (2001). Coping with ADD the surprising connection to green play settings. Environment \& Behavior 33(1): 54-77.

DOI: https://doi.org/10.33258/birex.v2i2.872 
Villeneuve, P. J., Jerrett, M., Su, J. G., Burnett, R. T., Chen, H., Wheeler, A. J. and Goldberg, M. S. (2012). "A cohort study relating urban green space with mortality in Ontario, Canada." Environmental Research 115:51-58. doi: 10.1016/j.envres.2012.03.003

Wolf, K.L. (2006). "Roadside Urban Trees: Balancing Safety and Community Values." Arborist News 15 (6): 56-58.

Wu, C., McNeely, E., Cedeño-Laurent, J. G., Pan, W., Adamkiewicz, G. and Dominici, F. (2014). "Linking student performance in Massachusetts elementary schools with the "greenness" of school surroundings using remote sensing." PLOS ONE. 9(10): e108548 doi: $10.1371 /$ journal.pone. 0108548

Yanga, J., mcbridea, J., Zhoub, J., and Sunb, Z. (2005). "The Urban Forest in Beijing and its role in Air Pollution Reduction." Urban Forestry \& Urban Greening 3: 65-78. 